\title{
Prospects of cold ironing as an emissions reduction option
}

\author{
Zis, Thalis
}

Published in:

Transportation Research. Part A: Policy \& Practice

Link to article, DOI:

10.1016/j.tra.2018.11.003

Publication date:

2019

Document Version

Peer reviewed version

Link back to DTU Orbit

\section{Citation $(A P A)$ :}

Zis, T. (2019). Prospects of cold ironing as an emissions reduction option. Transportation Research. Part A: Policy \& Practice, 119, 82-95. https://doi.org/10.1016/j.tra.2018.11.003

\section{General rights}

Copyright and moral rights for the publications made accessible in the public portal are retained by the authors and/or other copyright owners and it is a condition of accessing publications that users recognise and abide by the legal requirements associated with these rights.

- Users may download and print one copy of any publication from the public portal for the purpose of private study or research.

- You may not further distribute the material or use it for any profit-making activity or commercial gain

- You may freely distribute the URL identifying the publication in the public portal

If you believe that this document breaches copyright please contact us providing details, and we will remove access to the work immediately and investigate your claim. 


\section{Prospects of cold ironing as an emissions reduction option}

This is a pre-print of an article published in

\section{Transportation Research Part A: Policy and Practice}

The definitive publisher-authenticated version is available here:

https://www.sciencedirect.com/science/article/pii/S0965856418303264

Zis, T. P. (2019). Prospects of cold ironing as an emissions reduction option. Transportation Research Part A: Policy and Practice, 119, 82-95. 


\title{
Prospects of cold ironing as an emissions reduction option
}

\author{
Thalis Zis*
}

Department of Management Engineering, Technical University of Denmark, Produktionstorvet, 2800 Kgs. Lyngby, Denmark,tzis@dtu.dk 


\begin{abstract}
Cold ironing is the process of providing shorepower to cover the energy demands of ships calling at ports. This technological solution can eliminate the emissions of auxiliary engines at berth, resulting in a global reduction of emissions if the grid powering the ships is an environmentally friendly energy source. This paper conducts a literature review of recent academic work in the field and presents the status of this technology worldwide and the current barriers for its further implementation. The use of cold ironing is mandatory in Californian ports for ship operators and as a result terminal and ship operators were required to invest in this technology. In Europe, all ports will be required to have cold ironing provision by the end of 2025. Other regulations that target local emissions such as Emission Control Areas can have a significant impact on whether cold ironing is used in the future as a potential compliance solution. This paper constructs a quantitative framework for the examination of the technology considering all stakeholders. The role of regulation is shown to be critical for the further adoption of this technology. Illustrative case studies are presented that consider the perspective of ship operators of various ship types, and terminal operators that opt to invest in shorepower facilities. The results of the case studies show that for medium and high fuel price scenarios there is economic motivation for ship operators to use cold ironing. For the port, the cost per abated ton of pollutants is much lower than current estimates of the external costs of pollutants. Therefore, shorepower may be a viable emissions reduction option for the maritime sector, provided that regulatory bodies assist the further adoption of the technology from ship operators and ports. The methodology can be useful to port and ship operators in examining the benefits of using cold ironing as an emissions reduction action.
\end{abstract}




\section{Introduction}

Maritime shipping is considered the most fuel-efficient mode of transport in ton-miles terms, and moves about $90 \%$ of the global trade (UNCTAD, 2017). The third GHG study (IMO, 2014) estimates that shipping accounts for approximately $2.2 \%$ of the global anthropogenic $\mathrm{CO}_{2}$ emissions, representing a $0.5 \%$ decrease from the second GHG study estimates (IMO, 2009). However, the sector has seen increasing pressure, through new regulations, to improve its environmental performance, particularly in light of its contribution to harmful pollutant emissions on human health.

Maritime transport accounts for 5\% to $8 \%$ of the global $\mathrm{SO}_{\mathrm{x}}$ emissions (Eyring et al., 2005), and approximately $15 \%$ for $\mathrm{NO}_{\mathrm{x}}$ (Corbett et al., 2007), while PM emissions from shipping near coastlines and ports have been linked to fatalities attributed to respiratory health issues. The IMO is regulating the maximum sulphur limits in fuel through the revised MARPOL Annex VI, which also designated sulphur emission control areas (SECA) where tighter limits apply. Current SECAs include the Baltic Sea, the North Sea, the North American emission control area (ECA) that extends 200NM from the US and Canadian coasts, and the US Caribbean ECA. The latter two ECAs have also set restrictions on PM and NOx emissions. The first results of the SECAs on emissions reduction show significant improvements. In relevant literature, there has been no recent update on the share of maritime transport in $\mathrm{SO}_{\mathrm{x}}$ emissions, and the latest reliable estimate is in the aforementioned study of Eyring et al., back in 2005. On a more recent publication, Zis and Psaraftis (2018) used data from the Organization for Co-operation and Development (OECD) on its member countries and estimated that $\mathrm{SO}_{\mathrm{x}}$ emissions from all transportation modes accounted for $3.5 \%$ in 2015 . Considering that road transport accounted for $0.48 \%$, the share of maritime transport in $\mathrm{SO}_{\mathrm{x}}$ emissions has been drastically reduced since 2005 .

In addition to the introduction of SECAs, as of January 2010 the European Union (EU) set a sulphur limit of $0.1 \%$ for ships at-berth in EU ports with stays longer than 2 hours, as well as when sailing on inland waterways (European Commission, 2005). The European Commission has promoted the further provision of shorepower to its member states via an official recommendation (European Commission, 2006). Port authorities around the world have launched initiatives that promote use of low-sulphur fuel in their proximity, with the port of Singapore being a notable example under the Green Ship and Green Port programmes offering monetary incentives for clean practices that reduce $\mathrm{CO}_{2}$ and $\mathrm{SO}_{x}$ emissions. Finally, the ports of Los Angeles and of Long Beach have introduced voluntary speed reduction programmes (VSRP) in their proximity in return for a reduction of port fees, and are moving towards making the use of shorepower for ocean going ships compulsory.

With regards to regulations targeting sulphur emissions, ship owners can comply by either switching to ultra-low sulphur fuels such as Marine Gas Oil (MGO) or investing in scrubber systems that treat the exhaust gases to remove $\mathrm{SO}_{\mathrm{x}}$ and $\mathrm{PM}$ emissions thus allowing the use of Heavy Fuel Oil (HFO). Similarly, to cope with regulations on emissions at ports a ship can either use cleaner fuel or be retrofitted to receive shorepower if the port has cold ironing facilities. Therefore, to address environmental regulation the shipowners have to pay to acquire abatement technology, or increase their operating costs by using cleaner but pricier fuel. Which option is more cost-effective for the shipowner depends on various factors, including ship type, ship size, regulations affecting the waters in which the ship sails, and ports of call. At the same time, the decision of a port to invest in technologies that allow the provision of shorepower depends on several factors spanning from emissions reduction policies, and the penetration rate of the technology in the calling ships.

This paper discusses the feasibility of cold ironing (CI) investments from the perspective of shipowners, terminal operators, and regulatory bodies when considering the scope of environmental 
improvement that this technological solution can provide. The first section of this paper presents a concise literature review of relevant research in port emissions and use of CI. The subsequent section presents the methodology used for the assessment of an investment in such systems from all stakeholders, and expands on previous models to estimate the new environmental balance following the installation of a CI berth at a port. The third section considers the perspective of ship operators that retrofit ships of different types and the net present value (NPV) of their investments. A similar analysis is conducted from the perspective of a terminal operator that can choose to invest in a shorepower facility, and then decide the pricing strategy for the provision of electricity to the ships. The paper concludes with a discussion on the importance of the regulations on such technologies, the attained cost of reducing a ton of pollutant compared to other technologies, and the potential implications of internalizing external costs attributed to ship activity at ports.

\section{Literature review}

The majority of academic research on the environmental impacts of shipping has focused on the overall contribution of the sector, and on ways to mitigate emissions predominantly via slow steaming. However, effects near ports have not been extensively researched, with the majority of studies being technical reports of port authorities focusing on a very broad level of environmental concerns.

\subsection{Environmental impacts of shipping near ports}

Davarzani et al. (2016) conduct a literature review on greening ports and identify research areas for further investigation. They note that the focus on emissions from ships and port equipment is relatively new with a significant increase in publication numbers during the last decade. Slow steaming has been examined and shown to be a cost effective measure that simultaneously reduces carbon emissions (Golias et al., 2010). The reduction of sailing speed in the full journey also results in a small reduction of emissions in the proximity of the port (Zis et al., 2015). Johnson and Styhre (2015) consider environmental benefits from reducing port waiting times that would allow reduced sailing speeds at sea. More recently, there has been a resurface of sailing speed optimization problems particularly given the requirement of ships to switch to low-sulphur fuel that is more expensive. The research question of reducing sailing time within regulated waters has been formulated by Fagerholt and Psaraftis (2015) as an optimization problem dubbed the ECA refraction problem. Zis et al. (2015) propose a formulation for the speed optimization problem that considers ECA and speed restrictions near ports, which for the first time considers the abated pollutants in the port proximity.

\subsection{Port emissions inventories}

A limited number of studies specifically focuses on emissions in ports and their surrounding regions. These are either estimating emissions using bottom-up approaches based on fuel consumption estimations for ship activity at ports, or studies that are considering emissions concentrations from shipping using monitoring stations at ports and dispersion modelling. Saxe and Larsen (2004) modelled emissions of $\mathrm{NO}_{\mathrm{x}}$ and $\mathrm{PM}$ from three Danish ports using a meteorological air quality model. Deniz et al. (2010) used a bottom-up approach for various emissions species from ship calls in ten terminals in Turkey, considering main and auxiliary engines. They assume a universal load factor for auxiliary engines at $75 \%$ which is very high to represent all hoteling activities, and a $40 \%$ load for main engines during near-port cruise which again depends heavily on the specific ships visiting the ports, and the geographical layout of the port.

$\mathrm{Ng}$ et al. (2013) used AIS data to compile an emissions inventory for exhaust emissions of OceanGoing Vessels (OGV) in Hong Kong, and found that containerships were the top polluters. Tichavska and Tovar (2015) used a bottom-up methodology to estimate emissions from cruise and ferry 
operations in the Las Palmas using AIS data. They also proposed feasibility studies for various operational and technological measures that can reduce emissions from ships at ports. Dragovic et al. (2015) focus on near-port emissions from cruise ships, and their externalities with a case study on the cruise ports of Dubrovnik and Kotor. Of particular interest is their comparison of benefits of emissions reduction strategies (including scrubbers and $\mathrm{CI}$ ), with the commercial benefits of using the same budget for the extension of berthing space. A common attribute of the aforementioned studies is that these are limited to the estimation of the arising emissions from near-port activity. Cullinane et al. (2016) are using a bottom-up methodology to estimate emission at berth from containerships in the three largest ports in Taiwan. Their study is amongst the few that consider emissions reduction actions and quantifies their potential.

Outside the academic realm, various port authorities are reporting their emissions inventories on an annual basis. In the USA, a number of larger ports have developed inventories to comply with the State Implementation Plan (SIP) that was administered by the Environmental Protection Agency (EPA). The EPA itself is producing a national emissions inventory which includes an estimation on port-related emissions. In Europe, the European Sea Ports Organization (ESPO) that represents port authorities from 23 Member states of the European Union and Norway, has written a green guide to help its members achieve excellence in environmental management. The green guide encourages the creation and maintenance of all port-related emissions (ESPO, 2012) but does not require it.

\subsection{Provision of cold ironing as an emissions reduction option}

The potential of emissions reduction actions that ports can utilize has been considered for VSRP and CI, assuming partial to full participation (Zis et al., 2014). CI or Alternative Maritime Power (AMP) defines the procedure of providing electrical power to a ship at berth to meet the ship's energy demands while the ship's main and auxiliary engines are switched off. Military ships relied on electrical power from the shore for many years (Paul and Haddadian, 2005). The use of electricity in transport has been mainly associated with the benefits through electric vehicles that result in emissions generation at the source of the energy production facilities and not at the location of vehicle activity. Similar benefits can be observed in the maritime sector at ports where the ships are powered by the grid.

\subsubsection{Historical overview of cold ironing}

The term cold ironing is attributed to the practice of cooling down of the iron coal-fired engines while the ship was tied to the port in the past. Ships can use CI either from ship to ship (military applications) or from shore to ship with only the latter having environmental benefits. The benefits are predominantly local as the ships' funnels do not release pollutants in port. On the contrary, the energy demand of the ship is met by the power plant (or other sort of power) that provides current to the port. As a result, with the use of CI locally there are reduced ship emissions (at berth only the ship boilers will be working and still emitting). Globally, it will depend on the origin of the energy providing the shorepower (with increased emissions locally near the power supplier). The environmental trade-offs arising from CI have been examined in a series of conceptual case studies for ports with very different characteristics (visiting ships, size, type) in various parts of the world (Zis et al., 2014). Tseng and Pilcher (2015) consider the potential of shore power in the port of Kaohsiung and estimate the environmental benefits that would bring for different numbers of ships using the technology. They also provide qualitative insights based on interviews with port operators. On the technological side of CI, Sciberras et al. (2015) examine the effects of such systems on the electrical network (how other consumers powered by the grid are affected) and the quality of the delivered power to the ship. Prousalidis et al. (2014) considered combining CI with smart grids, and suggested performing a cost benefit analysis of $\mathrm{CI}$ as an emissions reduction technology on a case by case basis. Innes and Monios 
(2018) consider the economic feasibility of CI installations at smaller or medium size ports, and examine the offshore supply vessel port of Aberdeen. They calculate annual emission savings and find that under certain assumptions the external cost benefits would have a payback period of seven years without any other subsidies.

\subsubsection{Motivation for shorepower}

The use of AMP has been promoted in California with a regulation colloquially known as "At-Berth Regulation" that seeks to reduce emissions from auxiliary engines during hoteling. The main option is through the use of CI, or alternative technologies that result in the same reduction of $\mathrm{NO}_{\mathrm{x}}$ and $\mathrm{PM}$ emissions ( $70 \%$ currently, up to $80 \%$ by 2020). A similar motivation for CI had been in place in European ports, where since 2005 ships staying at EU ports for more than 2 hours, would be required to use ultra-low sulphur fuel or achieve similar reductions via alternative technologies including AMP as an option. Aside from these regulations, the use of CI could also have financial incentives in times of high fuel prices considering that power from the grid is sold at a lower price than fuel.

While certain regulations target specifically the emissions during hoteling, it does not follow that AMP will be used more widely. In Californian ports the local regulation stipulates that terminal operators are required to be able to provide shorepower; in the EU this is not the case. The EU regulation on at-berth emissions is targeting only $\mathrm{SO}_{2}$ emissions, the reduction of which is also the objective of SECAs. Therefore, a ship can switch to MGO (at berth or within the SECA), or alternatively use scrubber systems to comply with the regulation (Zis and Psaraftis, 2017). The latter, requires a significant investment that can exceed $\$ 6$ million per ship but offers compliance. The scrubber solution reduces PM emissions as well, but has a limited effect on $\mathrm{NO}_{\mathrm{x}}$. A paradox is evident; between 2005 and 2015 (the sulphur limit was $1 \%$ within SECA, $0.1 \%$ at berth) a ship calling at EU ports would have a higher incentive to invest in CI as it would replace the use of ultra-low sulphur fuel at the port. In other ports, the economic benefit of CI would be compared with the lower value of HFO. After 2015, due to the requirement to use MGO also at the sea (within SECA) the operator may be better off investing in a universal solution.

The emissions savings from ships relying on AMP to power their hoteling activities can be distinguished into local savings that the port enjoys and global savings (or additional emissions) if the at-source emissions are accounted for. Overall, the highest emissions reduction potential would be present for ports with relatively longer berth durations. Looking at specific pollutants, it can be expected that $\mathrm{SO}_{2}$ emissions reductions can be expected for non-EU and non-SECA ports where the baseline (relying on auxiliary engines) $\mathrm{SO}_{2}$ emissions would be significant due to the higher sulphur content.

\subsubsection{Current status of cold ironing worldwide}

In this section a compilation of ports around the world that currently provide or have decided to invest in shorepower is presented. In California, six ports are affected by the at-berth regulation; the ports of Los Angeles (POLA), Long Beach (POLB), Oakland, San Diego, San Francisco, and Hueneme (CARB, 2017). In Europe, one of the first implementations of CI was launched in Sweden. The Port of Gothenburg has two passenger and Roll-on/Roll-off (Ro-Ro) ferry terminals equipped with electric connections for CI. Ships at the terminals have assigned locations and run on regular scheduled routes. Ships were operated by a Ro-Ro operator which currently offers eight voyages per week between Gothenburg and Immingham, UK, and six voyages per week between Gothenburg and Ghent, Belgium. Shore-power is supplied by local surplus wind generated power and is therefore advertised as substituting fuel for renewable energy sources (RES). It should be noted that ferries have a low hoteling power demand: the ships receive shorepower only for lighting and ventilation purposes. In addition, ferries have no cargo-moving machinery and have little dockside activities. Therefore, the 
Gothenburg electrification process is much simpler than OGVs that are the target in Californian ports. The port authority estimates a reduction of 80 metric tons NOx, 60 metric tons $\mathrm{SO}_{\mathrm{x}}$ and 2 metric tons PM per year for the six weekly ships calling and using the installation. Terminal operators at Gothenburg claim that the power connection and disconnection is a process that takes less than 10 minutes to complete. However it should be noted that this is at an optimal setting with no complications. In reality, the total connection and disconnection time may be much higher due to the coordination that is required between ship and port crews, with times around 1 and 1.5 hour being more realistic as suggested by CARB. Whether a ship will actually receive shorepower may also be affected by berth availability, equipment failure, and other events that may actually limit the total time of using the AMP facility. The port of Antwerp has provision for seven onshore power connection points at one terminal, for barges. In Hamburg, LNG barges are deployed that provide power to ships at berth, effectively substituting MGO with LNG. Table 1 provides a list of known ports with shorepower provision capabilities. It is noteworthy that the power requirements span from relatively small tugs, up to large cruiseships and containerships across different ports. It can be observed that most installations are dedicated to either Ro-Ro, container, or cruiseships, with very limited installations for bulkers or tankers. This may be attributed to the fact that the former ship types tend to visit the same port multiple times, whereas the former may be running on the spot market, and thus show higher variability in their port calls. For these reasons, the case studies in this paper will involve only Ro-Ro, cruise and containerships. 
Table 1: Existing and planned cold ironing facilities in ports. Source: author's compilation and IAPH (2017)

\begin{tabular}{|c|c|c|c|c|c|c|c|}
\hline \multicolumn{2}{|l|}{ Europe } & \multicolumn{2}{|l|}{ North America } & \multicolumn{2}{|l|}{ Asia } & \multicolumn{2}{|c|}{ Oceania } \\
\hline $\begin{array}{l}\text { Antwerp (container, barges) } \\
\text { Zeebrugge (Ro-Ro) }\end{array}$ & Belgium & \multirow{18}{*}{$\begin{array}{l}\text { Halifax (cruise) } \\
\text { Montreal (cruise) } \\
\text { Vancouver (container, cruise) } \\
\text { Prince Rupert (container) } \\
\text { Los Angeles } \\
\text { (Ocean Going Vessels/ OGV) } \\
\text { Long Beach (OGV) } \\
\text { Oakland (container) } \\
\text { San Francisco (OGV) } \\
\text { San Diego (reefer ships) } \\
\text { Seatlle (cruise) } \\
\text { Juneau (cruise) } \\
\text { Pittsburg (bulk) }\end{array}$} & \multirow[t]{3}{*}{ Canada } & \multirow{9}{*}{$\begin{array}{l}\text { Baku (container) } \\
\text { planned } \\
\text { Shangai (cruise) } \\
\text { Qingdao (container) } \\
\text { V.O.Chidambaranar } \\
\text { (bulk) } \\
\text { Tokyo (cargo ships and } \\
\text { ferries) } \\
\text { Busan } \\
\text { Incheon } \\
\text { Ulsan } \\
\text { Yeosu Gqangyang }\end{array}$} & Azerbaijan & \multirow{2}{*}{$\begin{array}{c}\text { Auckland } \\
\text { (cruise) } \\
\text { planned }\end{array}$} & \multirow[t]{2}{*}{$\begin{array}{l}\text { New } \\
\text { Zealand }\end{array}$} \\
\hline Helsinki (Ro-Ro) & \multirow{4}{*}{ Finland } & & & & China & & \\
\hline Kemi (Ro-Ro) & & & & & & & \\
\hline Kotka (Ro-Ro) & & & \multirow{7}{*}{ U.S.A. } & & India & & \\
\hline Oulu (Ro-Ro) & & & & & Japan & & \\
\hline Le Havre & France & & & & & & \\
\hline Marseille (ferries) & Fiance & & & & & & \\
\hline Lübeck (Ro-Ro) & \multirow[b]{2}{*}{ Germany } & & & & S. Korea & & \\
\hline $\begin{array}{l}\text { Hamburg (Cruise) } \\
\text { power by LNG barges }\end{array}$ & & & & & & & \\
\hline Amsterdam (river boats) & \multirow{2}{*}{ Netherlands } & & & & & & \\
\hline Rotterdam (barges) & & & & Taipei & Taiwan & & \\
\hline Oslo (Ro-Pax) & \multirow{2}{*}{ Norway } & & & & & & \\
\hline Bergen (supply vessels) & & & & & & & \\
\hline Goteborg (Ro-Ro) & \multirow{4}{*}{ Sweden } & & & & & & \\
\hline Helsingborg (ferry) & & & & & & & \\
\hline Piteå & & & & & & & \\
\hline \multirow[t]{2}{*}{ Stockholm (Ro-Pax) } & & & & & & & \\
\hline & UK & & & & & & \\
\hline
\end{tabular}


At the current electricity price levels, on-shore electricity is reportedly less expensive than the electricity generation on-board. Finally, a reverse procedure where a ship may provide power to the grid can in theory occur should fuel prices allow it. Powerships (essentially floating powerplants) are also able to provide power to the grid, and a small number has been built to assist countries facing power shortages, with power outputs as much as 125MW per ship (Ataergin, 2015).

\subsubsection{Challenges and opportunities regarding AMP}

Compared to VSRP, slow steaming, or the use of low-sulphur fuel, the provision of CI for all ships can prove more challenging due to the barriers in the implementation of AMP and the required investments for ship owners and ports. The main barrier to the wider use of AMP has been the lack of compatibility between the ship and the grid as there is no uniform voltage and frequency around the world. The lack of standardisation in primary distribution voltage led to a variation from 440 volts to 11 kilovolts whereas some ships use 220 volts at 50 or $60 \mathrm{~Hz}$, and others rely on 110 volt current (Arduino et al., 2011). The load requirements also vary among different ship types and different sizes. Also, the significant retrofit costs on the ship side would only make sense for a ship that has considerable years of service left, and this may therefore exclude older ships. Khersonsky et al (2007) note two important difficulties in the further expansion of CI. The first is the additional cost of retrofitting existing ships to be AMP-ready. The second considers the limited space in ports to house the shore-side systems. Another factor that needs addressing and has not been done so in the literature is the issue of berth availability. Berth availability is shown to be a key factor in the competitiveness of a port (Yeo et al., 2008). Considering that in the beginning only a few berths will be able to provide shorepower, it is of outmost importance that when a retrofitted ship calls at the port, the respective CI-ready berth is free. Therefore, the berth scheduling of the terminal operator will have to change to ensure that retrofitted ships are served by the CI-ready berths, without this affecting the total time spent at the port (waiting for a berth that can result in a delayed departure of the ship). A final challenge is suggested by Innes and Monios (2018) who note that in the case of smaller ports, numerous small berths may require $\mathrm{CI}$ installations that will increase the costs due to additional units and longer cables required. However, there are opportunities that may help further expansion of the use of CI in the near future. Legislation and new regulations may also influence the expanded use of AMP across ports. CI could be a preferable alternative for ship owners due to the higher cost of the ultra-low sulphur fuel, if at-berth emissions are the only ones regulated. Given the worldwide trend to increase RES, CI can also reduce the environmental impact of ports also on a global scale too. The EU has set targets through its directives so that by $2020,20 \%$ of energy production in a member state is provided by RES, and it is expected that the percentage will increase in the future. CI can therefore be expected to bring higher emissions savings in the global balance in the future. The adoption of CI from ports around the world can also lead to a domino effect where more port operators are influenced and follow the examples of successful implementations. Tseng and Pilcher (2015) focused on Taiwan as an example and according to the results of their interviews, some port operators consider $\mathrm{CI}$ as the future and that this is an international trend they should follow.

\subsubsection{The chicken vs egg conjecture}

The main barrier for the further implementation of CI solutions in ports and ships is the associated high installation costs. From the perspective of the port, such an investment may lead to reduced emissions in the port area and thus a cleaner air quality, and an improved perception from the public. However, if there are not enough ships calling at the port that are capable of receiving shorepower, the benefits of installing AMP berths will be limited and alternative green investments may be preferable (e.g. renew handling equipment, offering incentives for speed reduction, use of clean fuel, or rewarding clean trucks at the gates of the port). From the ship operator's perspective, retrofitting 
the ship will improve their public perception, but the main driver will be the reduced operating costs from using electrical power instead of high-price low sulphur fuel. Therefore, in order to justify their investments, ship operators would want to use AMP facilities as much as possible. If only a small number of the ports of call are providing shorepower, then the ship operator may prefer alternative green options (for example installing scrubber systems that also work during cruise, consider wind energy options etc.). Depending on ship and terminal type, this matching may be more easy (for example for Ro-Ro ships that only sail between 2 or a few more ports), or very difficult (for example large containerships that visit more than 15 ports in their schedule, or tankers in the spot market). The previous can be considered as a chicken-egg dilemma, whereby ports will not invest until there are enough number of ships able of using AMP facilities, and ship operators will not retrofit until there are enough ports able of providing shorepower. One way to break this potentially infinite loop, would be to enforce the use of CI (as in the case of California), or at least require all ports to have some (limited) capability of providing shorepower (as in Europe by $31^{\text {st }}$ December 2025 through Directive 2014/94/EU). In the next section, a methodology to assess the economic and environmental feasibility of CI will be presented, and subsequently applied from the perspective of both the port and ship owner, for a small number of illustrative case studies. At this point it should be noted that from the port side, the decision maker is assumed to be the terminal operator. This could very well vary from port to port depending on the management and ownership model that a particular port follows. The different port management models have an effect on the efficiency and the competitiveness of the port (Tongzon and Heng, 2005). In case of a fully privatized port (e.g. in the United Kingdom), the owner of the port will have to invest in CI. For publicly owned ports, the port authority may invest in CI, or have the terminal operator invest as part of the contractual agreement between the two. Also, it may be that a port authority has leased different terminals to different operators and the decision to invest in CI would depend on each operator. It can be seen that who pays from the port side can be an important question, but is beyond the scope of this paper that examines the potential for the further adoption of CI around the world. Therefore, in the ensuing analysis, we consider that the terminal operator is the decision maker, be it the port authority or a private sector company running operating the terminal.

\section{Quantifying the impacts of cold ironing}

This section presents the fuel consumption at berth estimation for different ships and ports. Subsequently, the resulting emissions can be estimated at the port and compared with the emission savings from CI including the generated emissions at the source providing the shorepower. Finally, typical values for the external costs are provided for comparison purposes.

\subsection{Fuel consumption at berth}

A hoteling ship requires energy to cover demands of emergency equipment, refrigeration, cooling, pumps, heating, lighting and any other equipment running while the ship loads or unloads cargo and/or passengers. The fuel consumption $F C_{B, k}$ (tons) at berth $(B)$ of a ship $k$ relying on auxiliary engines for energy can be estimated through equation 1 as in Zis et al. (2014).

$$
F C_{B, k}(\text { ton })=\sum_{i \in\{a, b\}} 10^{-6} \cdot\left(S F O C_{i, B, k} \cdot E L_{i, B, k} \cdot E P_{i, k}\right) \cdot t_{B, k} \text {, for each engine } i \in\{a, b\}
$$

Where $S F O C(\mathrm{~g} / \mathrm{kWh})$ is the specific fuel oil consumption, $E L(\%)$ the fractional load of the nominal power $E P(\mathrm{~kW})$ of the auxiliary engines $(\alpha)$ and boilers $(b)$, and $t_{B, k}$ is the duration of the ship at berth.

For ships that are AMP-ready, the auxiliary engines may be switched off during berth and only the auxiliary boilers are operating $(i \in\{b\})$. The boilers keep fuel temperatures and the main engines' cylinders warm to avoid damage from low temperature contractions (Zis et al., 2015). Thus, 
in the proximity of the port, these auxiliary boilers are the only source of pollution. To identify the exact energy requirements to be provided through AMP, an activity based assumption may be used. The energy from the grid should be enough to cover the energy output that the auxiliary engines would provide if operating and include any energy losses due to transmission and energy conversion, typically estimated at $8 \%$ and $2 \%$ respectively (Zis et al, 2014).

\subsection{Emissions modelling}

Bottom-up emissions methodologies are retrieving emissions generation by multiplying fuel consumption with appropriate emission factors. In the context of this paper, the total port emissions $\varepsilon_{B}$ (tons of pollutant) for each engine $i \in\{a, b\}$ (auxiliary engines and boilers) on-board each ship $k \in\{N\}$ ( $N$ is the set of ships calling at the port) during their berth $(B)$ activities considered. These are equal to the fuel consumption $F C_{i, B, k}(\mathrm{~kg})$ of each engine $i$ multiplied by an appropriate emission factor $E F_{i, B, k}(\mathrm{~kg}$ pollutant $/ \mathrm{kg}$ fuel) as in equation 2.

$$
\varepsilon_{B}=\sum_{k \in\{N\}} E F_{i, B, k} \cdot F C_{i, B, k} \quad \text { for each engine } i \in\{a, b\}
$$

For some pollutant types, emission factors are fixed and depend only on the type of fuel used (e.g. $\mathrm{CO}_{2}, \mathrm{SO}_{2}$ ), whereas other pollutants depend on the engine speed (e.g. $\mathrm{NO}_{\mathrm{x}}$ ), or the $E L$ at which the engine is running (e.g. PM and BC). Table 1 presents the emission factors used in this paper.

\section{Table 1. Summary of emission factors}

\begin{tabular}{|c|cc|}
\hline Pollutant & \multicolumn{2}{|c|}{$E F$ (kg of pollutant/ kg of fuel) } \\
\hline & HFO & MGO \\
$\mathrm{CO}_{2}$ & 3.021 & 3.082 \\
$\mathrm{SO}_{2}$ & $0.02 * \mathrm{~S}$ (where S is the sulphur content) \\
& Slow and medium speed & High speed (auxiliaries) \\
$\mathrm{NO}_{\mathrm{x}}$ & 0.087 & 0.057 \\
$\mathrm{BC}$ & \multicolumn{2}{|c|}{$810^{-6} \cdot 33.519 \cdot \mathrm{EL}^{-0.754}$} \\
\hline
\end{tabular}

These emission factors require low-load corrections when operating at engine loads below $20 \%$ which are taken into consideration in the analysis. A more detailed discussion on emission factors can be found in the literature (IMO, 2014; Psaraftis and Kontovas, 2010; Lack and Corbett, 2012).

Through the use of CI there are always local environmental benefits since the auxiliary engines of participating ships are turned off for a large part (or even throughout) of the berthing time $\left(F C_{a, B, k}=0\right)$. However, there are induced emissions at the source of energy generation that now powers to the ship at berth. While some ports are investing in small power units (or Renewable Energy Sources - RES) for their own needs, the majority would rely on the grid to meet the very high energy demands from hoteling ships. To quantify these emissions, it is vital to know the energy mixture powering the port, and the relevant grid emission. Grid emission factors are usually lower than marine fuel emission factors since part of that energy comes from RES, nuclear power or more eco-friendly fuel (such as LNG). However, there are cases where the energy may be provided by coal-burning 
power plants with a worse environmental performance (particularly when low-sulphur fuel could be used at the port). Even in this case locally there would be significant benefits from the use of AMP.

The emission factors of the electricity grid are usually lower than the equivalent factors of fossil fuel used in internal combustion engines (particularly in comparison with marine engines using lower quality fuel than gasoline). There have been studies that compare the emissions from internal combustion vehicles and electric or hybrid cars in which the average grid emission factor per country is used. For example, Howey et al. (2011) assume a grid emission factor of $542 \mathrm{~g} / \mathrm{kWh}$ for the UK and use it to compare the environmental efficiency of electric vehicles with hybrid and conventional cars. The results depend heavily on the characteristics of the vehicles compared (aerodynamics, engine efficiency) and the country of study. A more recent estimate on the average grid emission factor in the UK for $\mathrm{CO}_{2}$ is $352 \mathrm{~g} / \mathrm{kWh}$ as seen in Table 2. A typical SFOC $(\mathrm{g} / \mathrm{kWh})$ for an auxiliary engine is 220 to $230 \mathrm{~g} / \mathrm{kWh}$ which if multiplied with the $\mathrm{CO}_{2}$ emission factor for MGO results in a range of 678 to 709 grams of $\mathrm{CO}_{2}$ per $\mathrm{kWh}$. A coal power plant has a $\mathrm{CO}_{2}$ emissions factor of $940 \mathrm{~g} / \mathrm{kWh}$, and the grid emission factor in countries (or States in the case of USA) with important indicative ports is shown in Table 2 (17). Table 2 is the product of a compilation of available sources on the emissions intensity, and energy mixture powering a grid. The numbers in Table 2 do not consider losses of energy during the transmission of power from the source to the user (in this context the port). The grid emission factors vary substantially each year, as the energy mixture is also changing. However, the correlation between a cleaner energy mixture (e.g. high on RES, Nuclear, low on coal) and the resulting grid emission factor is evident.

Table 2. Energy mixture data per country and average grid emission factors (Data source: European Commission (2017), EPA(2017), Moro and Lonza (2017) )

\begin{tabular}{|c|c|c|c|c|c|c|c|c|c|c|}
\hline \multirow[t]{2}{*}{ Port } & \multirow[t]{2}{*}{ Country } & \multirow[t]{2}{*}{ Coal } & \multirow{2}{*}{$\begin{array}{c}\text { Fuel } \\
\text { and } \\
\text { LNG }\end{array}$} & \multirow{2}{*}{ Nuclear } & \multirow{2}{*}{$\begin{array}{c}\text { RES } \\
\text { (including } \\
\text { Hydro) }\end{array}$} & \multirow{2}{*}{$\begin{array}{c}\text { Others } \\
\text { (including } \\
\text { waste, } \\
\text { imports) }\end{array}$} & \multicolumn{4}{|c|}{ EFgrid $^{I}$} \\
\hline & & & & & & & $\begin{array}{c}\mathrm{CO}_{2} \\
(\mathrm{~g} / \mathrm{kWh})\end{array}$ & $\begin{array}{c}\mathrm{SO}_{2} \\
(\mathrm{~g} / \mathrm{kWh})\end{array}$ & $\begin{array}{c}N O_{x} \\
(g / k W h)\end{array}$ & $\begin{array}{c}P M 2.5 \\
(g / k W h)\end{array}$ \\
\hline $\begin{array}{c}\text { Los } \\
\text { Angeles }\end{array}$ & $\begin{array}{c}\text { USA } \\
\text { (California) }\end{array}$ & 0.4 & 61.1 & 8.6 & 23.4 & 6.5 & 251.1 & 0.045 & 0.091 & 0.002 \\
\hline Virginia & $\begin{array}{c}\text { USA } \\
\text { (Virginia) }\end{array}$ & 26.9 & 29.1 & 39 & 5 & 0 & 397.7 & 0.408 & 0.318 & 0.003 \\
\hline Juneau & $\begin{array}{c}\text { USA } \\
\text { (Alaska) }\end{array}$ & 31.7 & 32.5 & 27.6 & 8.1 & 0.1 & 478 & 0.726 & 0.318 & NA \\
\hline Seattle & $\begin{array}{c}\text { USA } \\
\text { (Washington) }\end{array}$ & 5.8 & 9.8 & 8.2 & 76.1 & 0.1 & 101.7 & 0.045 & 0.045 & NA \\
\hline Felixstowe & UK & 4.3 & 40.1 & 15.3 & 10 & 0.9 & 388.8 & 0.3 & 0.7 & 0.049 \\
\hline Gothenburg & Sweden & 0.3 & 0.5 & 43 & 54.3 & 1.8 & 10.5 & 0.0069 & 0.03 & \\
\hline Hamburg & Germany & 34.6 & 11.6 & 19.1 & 31.3 & 1.1 & 424.9 & 0.211 & 0.577 & 0.052 \\
\hline Antwerp & Belgium & 6.2 & 27.3 & 47.2 & 18.8 & 0.5 & 207 & 0.125 & 0.397 & 0.059 \\
\hline Sydney & $\begin{array}{c}\text { Australia } \\
\text { (New South } \\
\text { Wales) }\end{array}$ & 32.2 & 62 & - & 5.8 & 0 & 830 & 2.1 & 1.3 & 0.003 \\
\hline Shanghai & China (East) & 58.6 & 4.7 & 2.1 & 34.6 & 0 & 837 & $4-7.3$ & $2-3.7$ & NA \\
\hline
\end{tabular}


Technologically the efficiency of the grid is gradually improving over the years aided by the strict regulation to increase the participation of RES in the energy mixture. Further reductions to grid factors can be expected that with the growing introduction of RES in a country's energy mixture, and thus greater environmental benefits through CI can be anticipated. In maritime transportation, and AMP in particular, the comparison can be made in terms of electric requirements at berth which would typically be the same for a given ship in a given port during the same time. This comparison is shown in Figure 1, for four pollutant species.

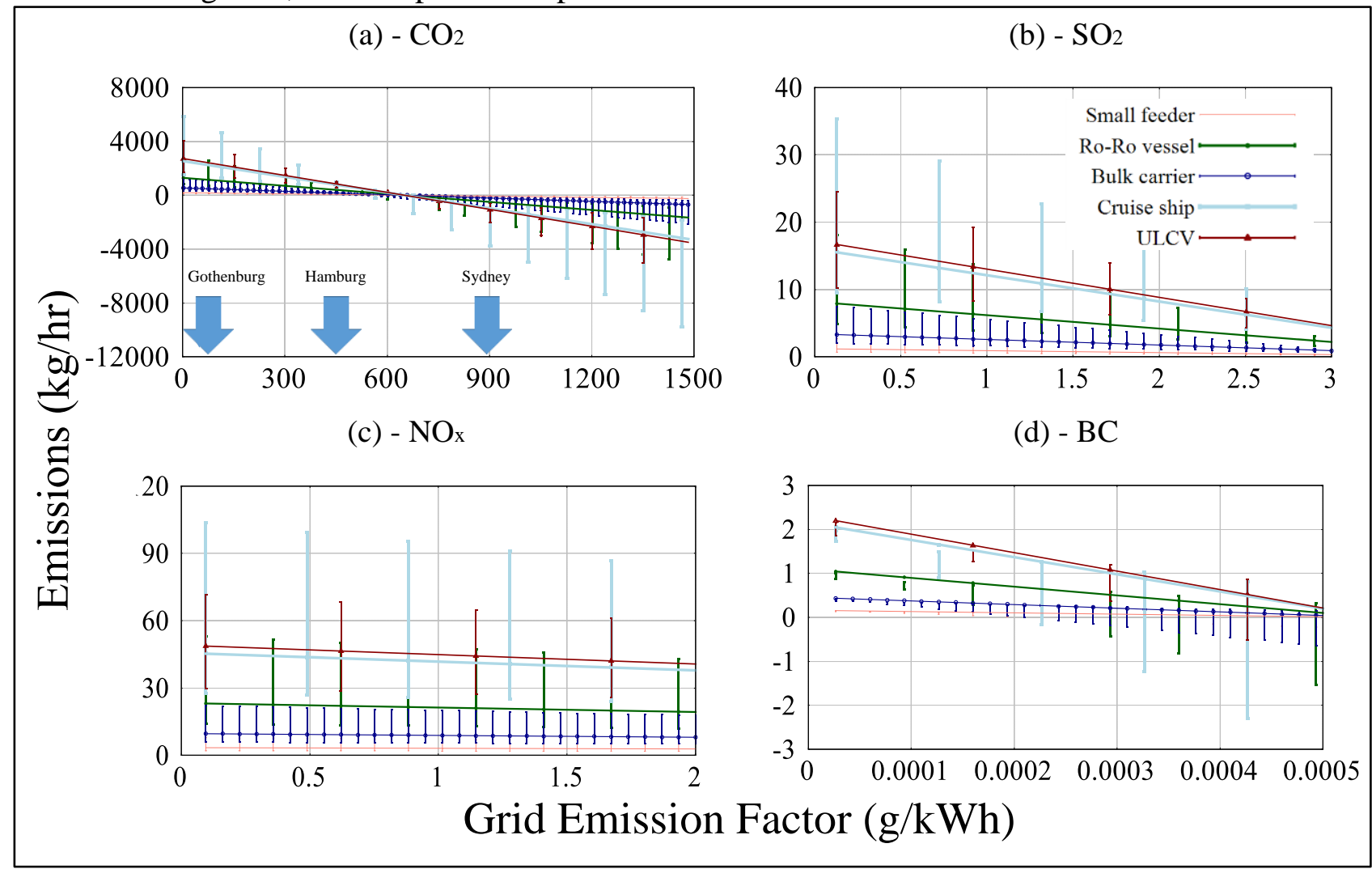

Figure 1: Balance of global emissions when using cold ironing, as a function of grid emission factors

The error bars in the four plots depict the variation in energy demands for different $E L_{a, b}$ (a minimum of $10 \%$, and an average/maximum that varies according to ship type). For all four plots it can be easily observed that the emissions balance is a line that for low $E F_{i, g r i d}$ values is positive and will become negative at less clean grids. The point where each line intersects the $\mathrm{x}$-axis is essentially the point where the grid emissions factor considering conversion and transmission losses is equal to the emissions factor of the auxiliary engine. For the $\mathrm{CO}_{2}$ emissions balance, the performance of 3 ports is also plotted on the $\mathrm{x}$-axis to facilitate comparisons.

\subsection{Basic economics of cold ironing}

The use of CI requires significant capital investments from both the port authority, and the shipowner. The decision of a shipowner to use AMP during one or more of their port calls depends on several economic factors. Most importantly, the shipowner may have to retrofit the ship to be able to receive shorepower with significant capital required $C_{R, k}$. An indicative cost for an OGV was reported at around $\$ 400000$ (Arduino et al., 2011). The IMO (2017) provides some more recent estimations on 
the implementation costs of CI for different ship types. These cost vary significantly as for example smaller ships of up to 5000 GT can require anywhere between $\$ 50000$ and $\$ 350000$, while larger ships greater than 100000 GT (containerships, crude oil tankers, large cruise ships) can require up to $\$ 750000$. In general retrofitting a ship is more costly than installing AMP capability in a new-build. During each year, the economic balance $\triangle C_{A M P, k}(\$)$ of ship $k$ calling $N_{c, k}$ times at ports with CI capability $(c)$ and receiving shorepower can be calculated using equation 3.

$\Delta C_{A M P, k}=\frac{C_{R, k}-S_{R, k}}{\left(1+r_{k}\right)^{y}}+N_{c, k} \cdot\left(t_{L, A M P, k} \cdot C_{t, k}+P_{A M P} \cdot E_{A M P, k}-F C_{a, B, k} \cdot P_{f, a}-R_{A M P, P, k}\right)$

Where $S_{R, k}$ is a potential subsidy provided by a port towards retrofit costs and the first term (fraction) is the present value of the initial retrofit costs $y$ years after the retrofit assuming an interest rate $r_{k}$. The term $t_{L, A M P, k}$ is the time lost during each call for plugging and unplugging the ship with a value of time $C_{t, k}$. Finally, $R_{A M P, P, k}$ is any incentive provided per call from the port authority $P$ to the ship. From equation 3 it can be assumed that if the ship is already able to connect to shorepower (as some newly built ships are designed to be to be compliant with Californian regulation), the decision to use AMP or not at each call will depend on the price per $\mathrm{kWh}$ as sold by the port authority, any additional monetary incentive provided, the cost per ton of fuel at berth and the AMP-berth availability during each call. Monetary incentives during each CI ship call have not been introduced directly by port authorities, however a deduction in the price per $\mathrm{kWh}$ sold has been considered in some cases as a means to promote the use of AMP. In other ports (e.g. Marseille) a deduction in the port fees for ships using CI has been introduced. Finally, the port of Stockholm is providing a subsidy of up to 0.5 million SEK (approximately \$62000) towards the retrofit of Ro-Ro ships that call at the port, subject to a 3-year commitment of visiting the port of Stockholm.

For the port authority, a typical cost for the installation of an AMP berth is estimated at $\$ 1.5$ to $\$ 2$ million (as reported in the current IEC/ISO standard 80005), but this figure may change depending on the terminal type. For example, in their recent paper Innes and Monios (2018) suggested a cost of $£ 6.6 \mathrm{~m}$ for 9 berths to power offshore supply vessels (that have less energy requirements at berth than large containerships or passenger ships) which is equivalent to $\$ 0.97$ million. A recent implementation in the port of Seattle for cruisehips costed $\$ 1.5$ million. It should be noted that these costs will also slightly differ depending on the terminal layout and on how far apart are the different berths where ships stay at (different cable lengths required). To summarize, the annual costs borne by the port authority will therefore depend on:

- the terminal type and layout

- the number of berths $N_{B}$ able to provide shorepower,

- the annual operating costs $C_{A M P, O, P}$ (including maintenance, staff costs)

- the number $n$ of ships $k$ using AMP at their calls,

- the price $P_{\text {grid }}$ per kWh sold by the grid,

- the price $P_{A M P, k}$ per kWh sold to the calling ship $k$,

- monetary incentives $R_{A M P, k}$ provided to a ship to influence a decision to use AMP and finally

- $\quad$ potential subsidies $S_{R, k}$ provided to a ship towards retrofitting costs

The previous are summarized as annual costs, assuming a discount rate of $r_{P}$ in equation 4 .

$$
C_{A M P, P}=N_{B} \cdot \frac{C_{A M P, I, P}+C_{A M P, O, P}}{\left(1+r_{P}\right)^{t}}+\sum_{k=1}^{n}\left(\frac{s_{R, k}}{\left(1+r_{P}\right)^{t}}+R_{A M P, k}+P_{g r i d} \cdot E_{g r i d, k}-P_{A M P, k} \cdot E_{A M P, k}\right)
$$

With the exception of California where AMP is heavily promoted and complemented by regulations that enforce OGVs to use it, it can be expected that a ship would only use AMP if it is 
financially beneficial. Therefore, it can be expected that the fuel price will be a key factor as to whether a ship relies on AMP, and particularly in ports bound by either ECAs or EU regulations (demanding pricier ultra-low sulphur fuel at-berth). The economics of CI has been a recurring theme in technical and academic literature with most studies emphasizing the importance of prices per $\mathrm{kWh}$ (Winkel et al., 2015; Fiadomor, 2009). To elaborate on the impacts of electricity prices, Figure 2 compares the cost of electricity between using different marine fuel (we use half-year averages for fuel types MGO $0.1 \%$ sulphur, HFO $1 \%$ sulphur) and the industrial rate at different countries (these are reported in half-year averages in Eurostat and IEA).

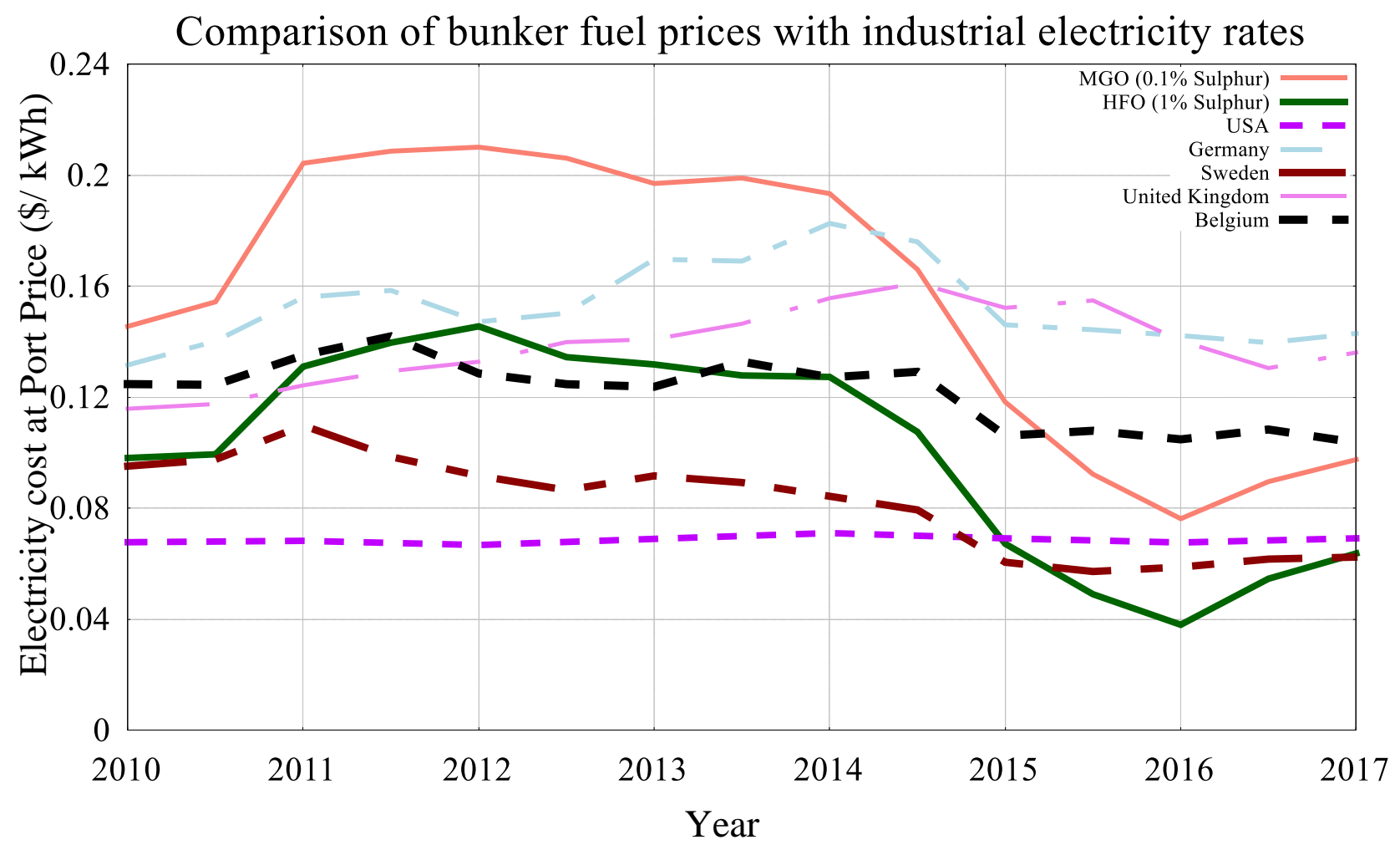

Figure 2: Cost of generating $1 \mathrm{kWh}$ of power using marine fuel vs buying $1 \mathrm{kWh}$ from the national grid

Both fuel types (MGO and HFO) follow similar trends, with a surprising drop in fuel prices after the second half of 2014. In contrast, the electricity prices are less volatile. From a cost perspective, CI would be more beneficial economically for ship operators calling at US ports, or Sweden rather than Germany. In recent years due to the unexpected drop in fuel prices (Zis and Psaraftis, 2017) the benefits of using CI are now lower, to the point that in some countries it may be cheaper to keep using MGO at berth. HFO with $1 \%$ sulphur content can be used in certain countries, but not in European ports, or in California, unless a scrubber is installed at the ship that can treat exhaust gases from auxiliary engines. Finally, the data in Figure 2 are not considering any transmission/conversion losses from the grid to the ship, therefore the actual costs for the ship operator using CI may be higher due to a slightly higher energy demand to cover for the aforementioned losses. The next section will present a set of illustrative case studies to facilitate discussion in understanding the future prospects of $\mathrm{CI}$ in the quest for environmentally friendly port operations.

\section{Analysis}

This section considers the perspective of a ship owner and a port operator that opt to invest in CI, for a few illustrative case studies. The net present value (NPV) is used to assess financially the 
investment for each stakeholder. The analysis assumes three different fuel price scenarios (low, medium, high) based on recent fuel prices. Depending on ship type, a different investment period is considered for each case study.

\subsection{Ship operator retrofit}

This case study considers the perspective of different ship operators that invest in retrofitting the ship to receive shorepower. For each case, the NPV of the capital investment CAPEX (\$) to retrofit the ship is used as an assessment tool. The NPV is calculated with the equation 5:

$$
N P V=C A P E X+\sum_{t=0}^{T} \frac{\Delta C_{A M P, k}}{\left(1+r_{k}\right)^{t}}
$$

where $\Delta C_{A M P, k}(\$)$ is the annual cost or benefit of using $\mathrm{CI}$ at the port taken from equation 3 , and $T$ (years) is the remaining lifetime of the investment.

\subsubsection{Ro-Ro ship}

The case study assumes that the Ro-Ro ship is sailing two times a week (two roundtrips) between two ports A and B in Sweden and Belgium respectively, with average berth duration of 8 hours at each port and a sailing time of 34 hours. The port in Sweden can currently provide shorepower, and it is assumed that the ship will be connected at every stay. The cost benefit analysis is conducted for three different fuel price scenarios (low, medium, and high) and examining the impact of having the second port offering CI. The project's investment period is assumed to be 10 years, after which the ship may be out of service due to the age of the ship. The electricity price per $\mathrm{kWh}$ was calculated based on data from Eurostat for industrial consumers, and using the average value of the examined countries.

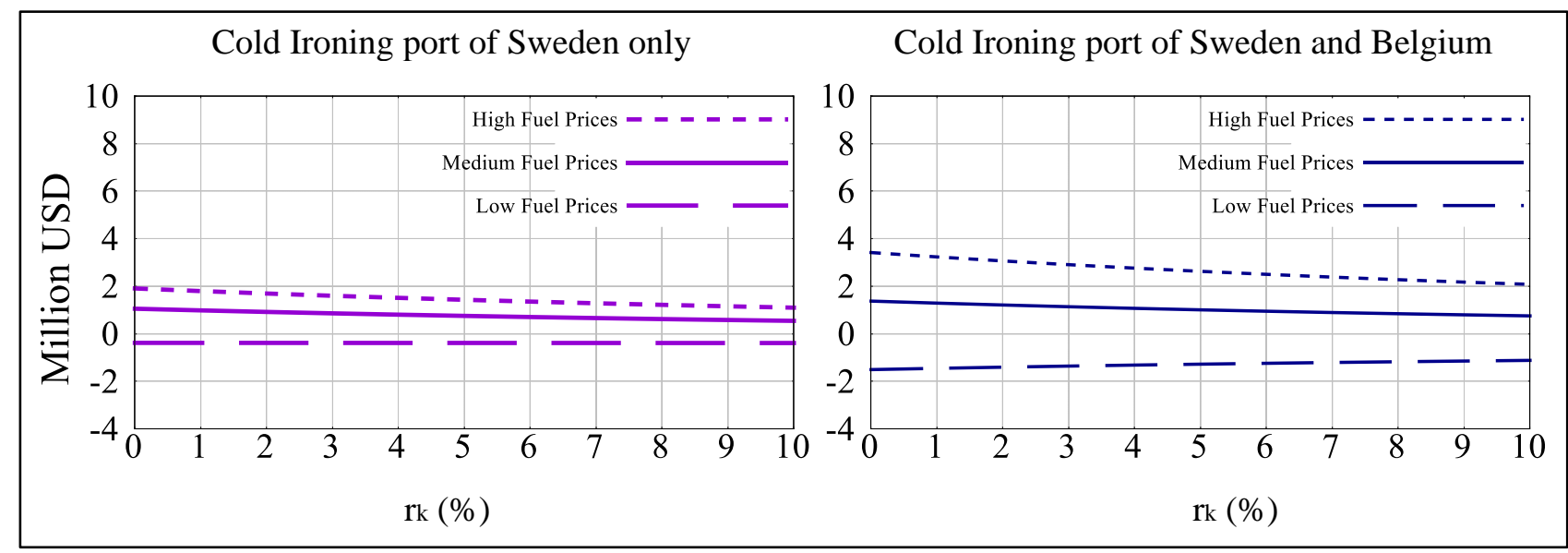

Figure 3: Economic evaluation of cold ironing retrofit on a small Ro-Ro ship

The results show that for medium and high fuel prices investing in $\mathrm{CI}$ is economically beneficial for the ship, whereas for the very low fuel prices the energy cost savings are not enough to pay off the investment within the lifecycle assumed in this case. If the second port (Belgium) also introduces shorepower, these benefits are increased and the investment has a higher return. To further comprehend the impact of the price per $\mathrm{kWh}$, a similar analysis is performed in Figure 3 assuming the same ship having a similar service but at different countries with one or both two ports providing shorepower (using the same price per $\mathrm{kWh}$ at both ports in each scenario) for only the medium fuel price scenarios. Results show that, for the investment to be successful, it is critical that both ports have AMP capability, and that it is a better option for ships calling at ports with low sulphur 
requirements. The AMP option is a much better option at times of high fuel prices. Due to the currently low number of ports that offer CI, from the ship operators perspective it may be better for such ship types in comparison to containerships that call into multiple terminals per year, and as a result will have less time using the AMP infrastructure.

\subsubsection{Cruise ship}

This case study concerns a large cruise ship capable of hosting approximately 2500 passengers. The ship is spending a large part of its annual season sailing between Alaska, Canada, California and Mexico where it is assumed to be able to connect to the ports of Vancouver, and Juneau. A smaller part of its journey (December - April) it cruises around Asia (Japan, South Korea, Taiwan, and China) and it is assumed to be able to receive power from the ports of Shanghai, Incheon, and Busan. The scheduled at berth hours of the cruise ship are 2115, of which 362 are scheduled at ports that can provide shorepower. Figure 4 illustrates the NPV profile for the cruise ship for the realistic case where the ship uses shorepower at all ports with current AMP capability, and the hypothetical case where all ports of call could provide this power. The NPV is calculated assuming a 20 year period the ship will be operating.

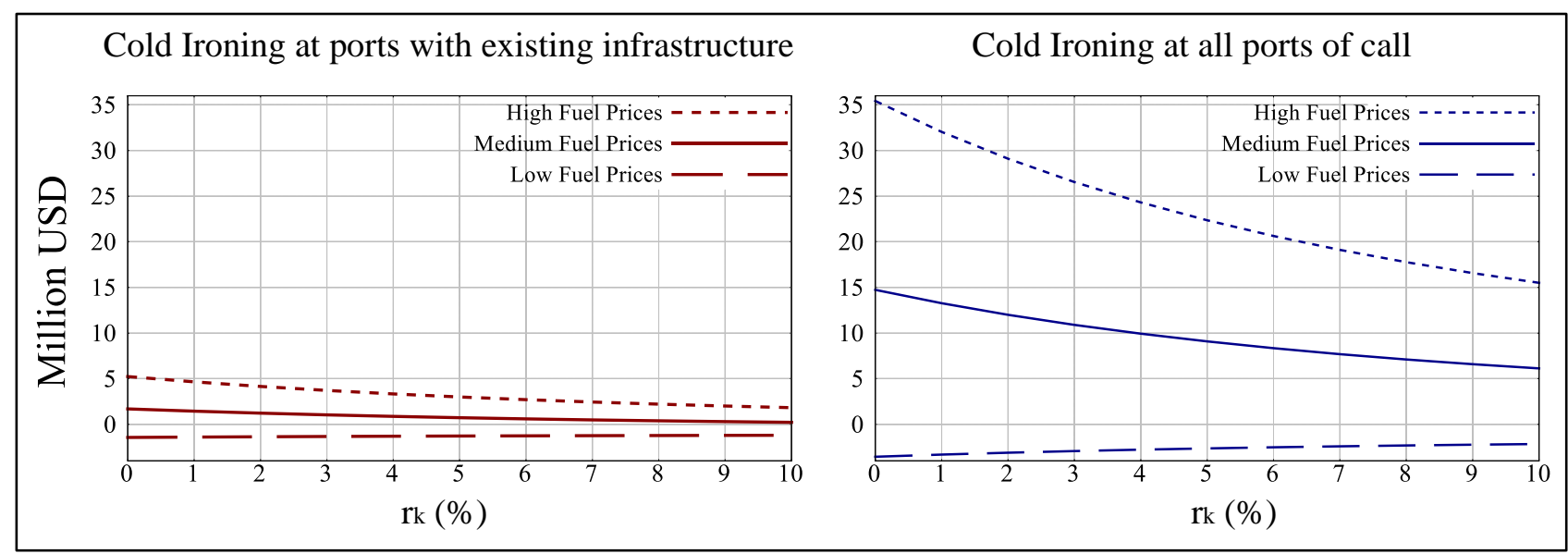

Figure 4: Economic evaluation of cold ironing on a large cruiseship

Similar to the previous case study it is evident that for high fuel prices the investment if more profitable, unlike for low fuel price scenarios. In addition, if all ports were able of providing shorepower the return of the investment would be much higher.

\subsubsection{Ultra large container vessel (ULCV)}

ULCVs are claimed of transporting a maximum of 21413 TEU (OOCL, 2018) and were equipped with CI capabilities upon building. These ships are currently sailing in Asia-Europe routes, and typically spend (according to published schedules from liner companies) approximately $25 \%$ of their time at ports for loading and unloading operations. In this section the OOCL Hong Kong ship is used for a hypothetical case study. As of 2018, this ship is deployed on a 77-day roundtrip calling at 9 different ports of which none can provide shorepower. Figure 5 presents the NPV profiles of an investment (assumed at an extra 1 million USD) for a different penetration rate of CI provision at the ports of call. For the cost of electricity, the analysis assumes a $0.12 \$ / \mathrm{kWh}$ rate in Asian ports, and a $0.134 \$ / \mathrm{kWh}$ in the European ports of call (based on EU average). The assumption is that first the European ports ( $25 \%$ of calls onward) will provide first shorepower to this size of ships. 


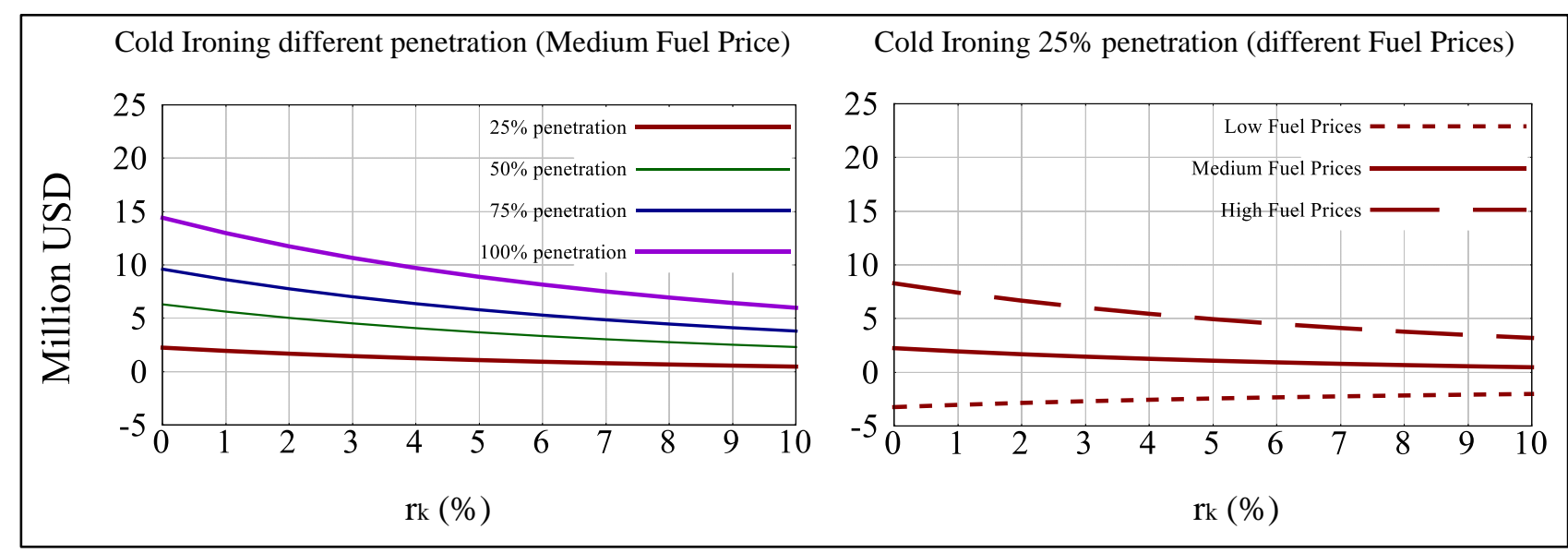

Figure 5: Economic evaluation of cold ironing on an ULCV, for different penetration rates of shorepower in ports of call and varying fuel price scenarios

Figure 5 shows that for medium or high fuel price scenarios, investing in $\mathrm{CI}$ is beneficial for the new built ULCV, if $25 \%$ or more ports of call can provide this power. For higher penetration rates the return of the investment is much higher. However, this analysis assumes that the ship can always receive power if the port of call has the infrastructure. In reality, there may be issues with AMP-ready berth availability that may limit the actual usage of the technology for an individual ship.

\subsubsection{Panamax containership}

This case study is focusing on a Panamax containership (5100 TEU capacity) that is deployed on a Trans-Pacific route that has been retrofitted to comply with the At-Berth Regulation in the Californian ports. The ship spends approximately $13 \%$ of its time at ports. The ensuing analysis considers three cases; for the first one, the ship is only using shorepower at Californian ports (to comply with regulation), the second considers that the ship is also using it in the Asian ports that can currently provide the power (S. Korea, Japan), and the final one is considering a scenario where all ports can provide shorepower. The retrofit cost for a containership of this size is considered at $\$ 0.5 \mathrm{M}$ and the remaining lifetime of the ship is taken as 20 years. The results are shown in Figure 6 for three fuel price scenarios.

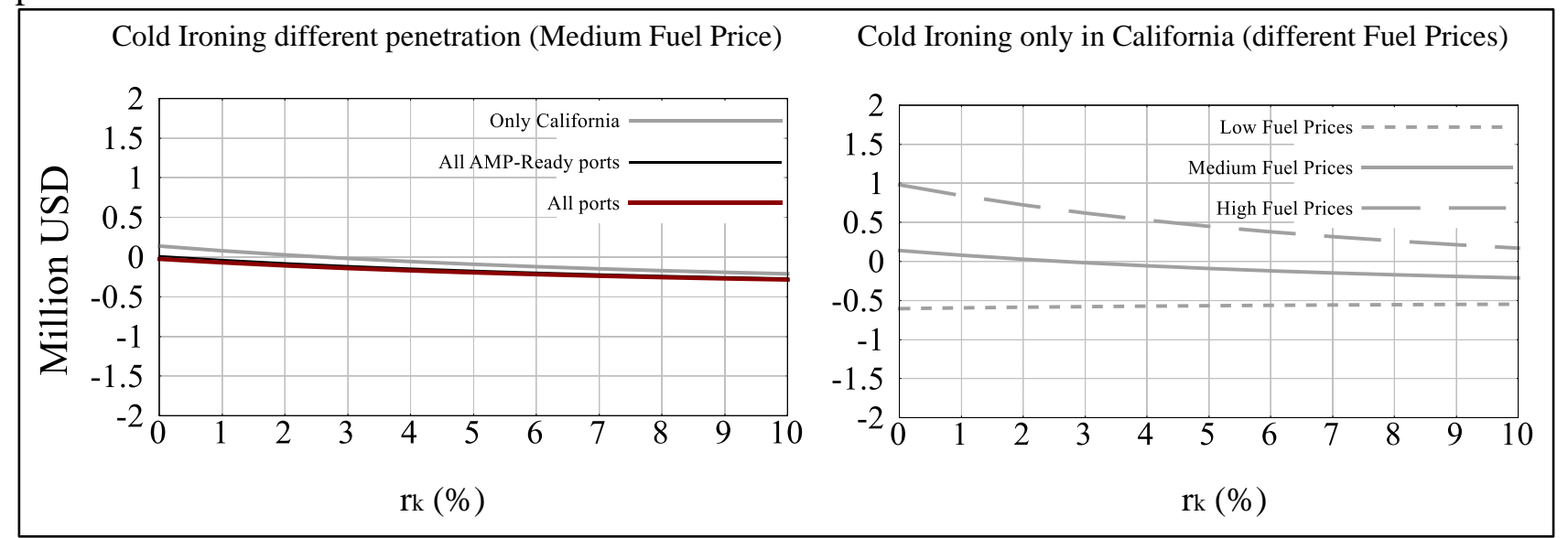

Figure 6: Economic evaluation of cold ironing for a Panamax ship, that is calling in California and is retrofitted

The results show that this investment may have some minor economic benefits for high and medium fuel prices scenarios. In comparison with the previous ships examined, this particular ship spends a lower time of its service time at ports. Regardless, for medium and high fuel price scenarios there 
would be a return of investment even if the ship is only using CI in California (where it is required by regulation).

\subsection{Port authority}

This case study considers the perspective of a port authority that seeks to maximize the emissions reductions of a specific pollutant from ship activity in its proximity. The case study considers a container terminal of a 1.3 million TEU annual throughput, with 1700 ship calls per year. A 2-week cycle is assumed for the terminal that has 3 discrete berths. An AMP berth is assumed to cost \$2 million to build. The analysis considers that the port authority can be either a:

- "Neutral" port that sells the power at exactly the cost of purchasing power from the grid,

- "Super Green" port that gives the power for free (as a measure to promote CI retrofits to visiting ships)

- "Greedy" port that makes a profit on selling the power ensuring that the cost to the shipowner will be $10 \%$ lower than relying on fuel at port.

The analysis considers four cases where the usage of the AMP berth varies from 2000 up to 8000 hours per year, and assumes an average ship to estimate emissions savings in the port proximity. Figure 7 presents the economic evaluation of the installation of an AMP berth for different port behaviors as well as the cost per abated ton of $\mathrm{CO}_{2}$ for ports that are not making a profit on the $\mathrm{kWh}$ (including $\mathrm{CO}_{2}$ emissions at the source, here California).

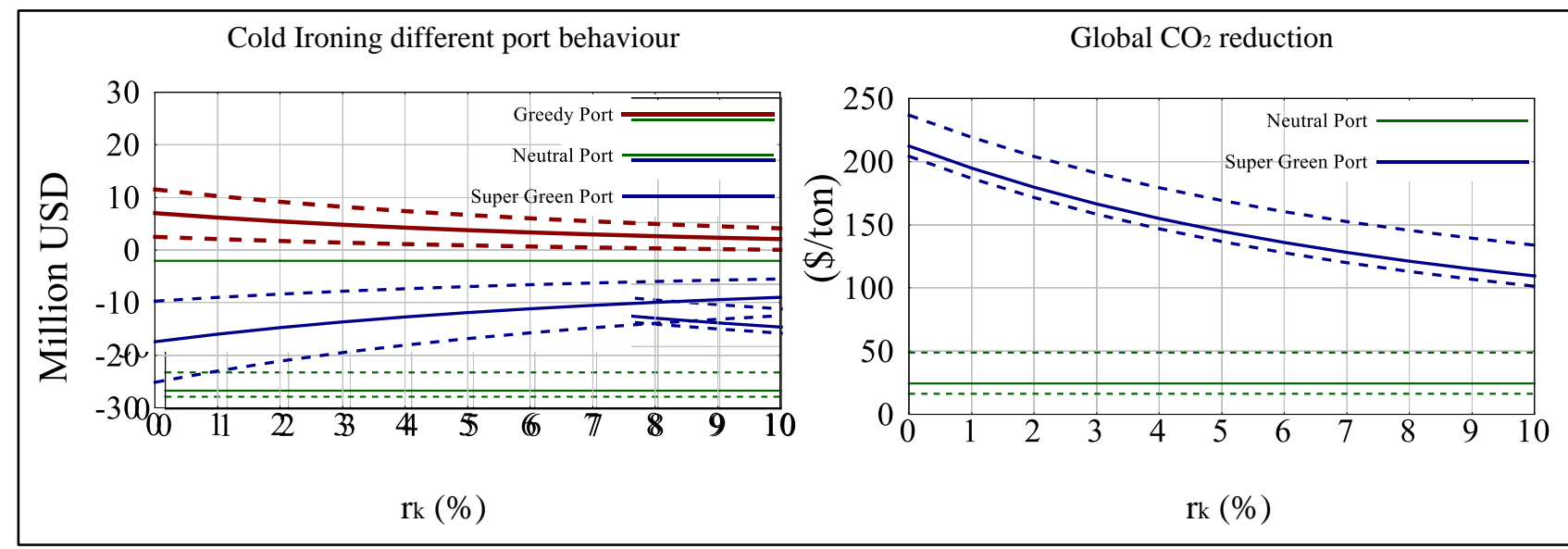

Figure 7: Economic analysis of AMP installation at a berth, and cost per (global) abated ton of pollutant from the port operator's perspective

It can be seen that for the Neutral port, essentially the return of investment is the reduced environmental emissions. A greedy port operator would enjoy additionally economic gains by selling the $\mathrm{kWh}$ at a higher rate than bought from the grid. Finally, the unrealistic scenario where the port pays for the power used by the ship, it is obvious that the cost per abated ton is increasing. Considering that $\mathrm{CI}$ is mainly advertised as a local emissions pollutant reduction measure, an additional analysis is conducted to estimate the ton per abated local savings for $\mathrm{CO} 2$ and NOx emissions. Local CO2 emissions reduction could in theory be of interest if the port is included in Emissions Trading Schemes (ETS), while the cost of NOx emissions reduction can be compared with alternative green options. The results are shown in Figure 8. 


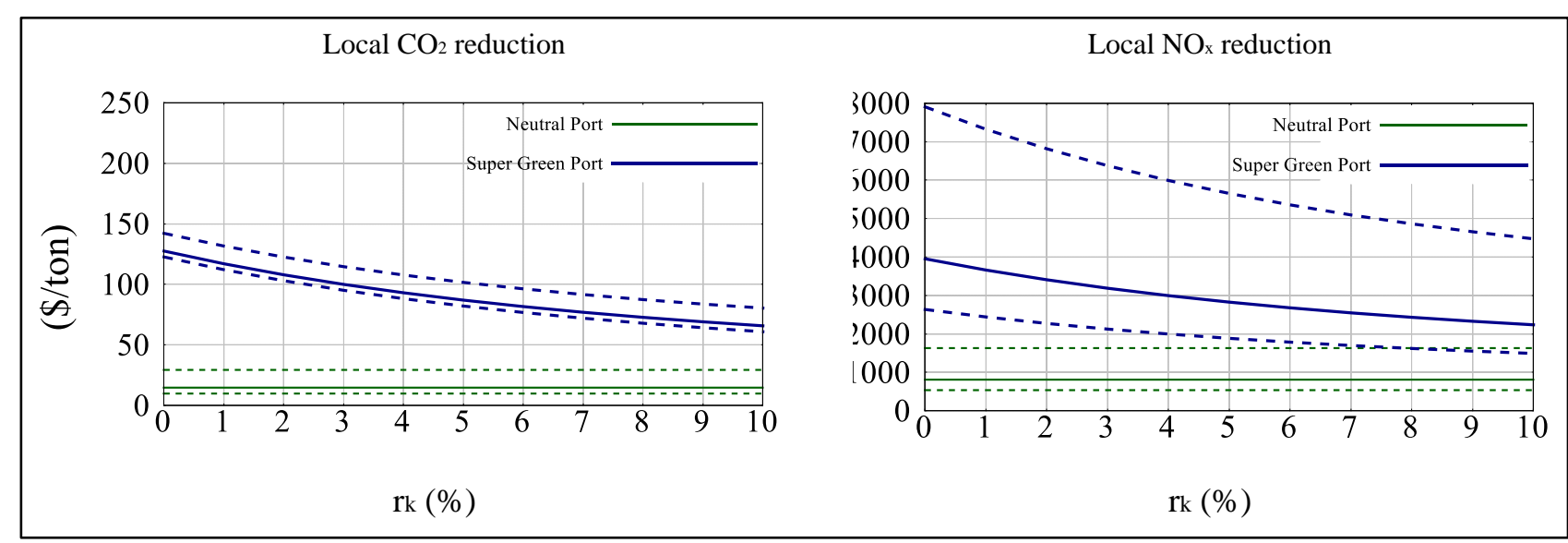

Figure 8: Cost per (local) abated ton of pollutant for $\mathrm{NOx}$ and $\mathrm{CO}_{2}$

From the results shown in Figure 8 we observe that the cost per abated ton is reduced with a higher usage of the AMP facility. For the neutral port, this cost can vary between $\$ 10$ to $\$ 30$ per ton of $\mathrm{CO}_{2}$, and between $\$ 540$ and $\$ 1600$ per ton of $\mathrm{NO}_{x}$. These numbers are promising when compared with estimations of external costs of transport. For comparison purposes, Table 3 provides average values in Europe based on the Handbook on external costs of transport in Europe (Ricardo-AEA, 2014) that vary depending on area.

Table 3: External Costs of Emissions in Seas in EU. Source: Ricardo - AEA (2014)

\begin{tabular}{|l|r|r|r|r|}
\hline \multirow{2}{*}{ Pollutant } & \multicolumn{4}{|c|}{ Unit Values for Main pollutants in sea areas (€/ton) } \\
\cline { 2 - 5 } & $\mathrm{CO}_{2}$ & $\mathrm{SO}_{2}$ & $\mathrm{NO}_{\mathrm{x}}$ & \multicolumn{1}{c|}{$\mathrm{PM}_{2.5}$} \\
\hline Baltic Sea & & 5250 & 4700 & 13800 \\
Black Sea & & 7950 & 4200 & 22550 \\
Mediterranean & 90 & 6700 & 1850 & 18500 \\
North Sea & & 7600 & 5950 & 25800 \\
\hline
\end{tabular}

Therefore, from an environmental perspective CI can be a very good measure for port operators, if the penetration rate of AMP-ready ships visiting the port is high. A potential requirement for internalization of external costs of transport could improve further the economic prospects of CI as an emissions reduction option.

\section{Conclusion and further research}

This paper presented a methodology to assess the implications of providing shorepower to ships during their hoteling activities. Research in the field of CI has seen an increased interest in recent years following the introduction of evermore environmental policies seeking to reduce emissions from maritime shipping. The methodological framework constructed in this work can be useful to ports and ship operators in deciding whether to invest in AMP applications. The analysis showed that some of the environmental regulation can have a positive impact on the further development of AMP as a technological solution. This is evident as when there are high fuel prices the cost of electricity from the grid tends to be significantly lower, and as a result provide lower operating costs when relying on CI. Therefore, low sulphur regulation near ports may have provided additional motivation to shipowners to invest in CI. However, when such regulation affects the whole journey of a ship (e.g. SECAs, the global sulphur CAP from 2020) this may result in ship operators investing in universal solutions such as scrubbers instead of CI. However, from a local air quality 
perspective, a ship using CI is preferable to one having a scrubber or using MGO at berth. As stated in the paper, the major barrier to further implementation of shorepower in maritime shipping, is the lack of enough ports that have this technology, and the relatively low penetration rate of retrofitted ships. In time, newer ships may come ready with CI capability, and port authorities may start investing further due to regulation (as in the European Union from 2025).

Perhaps a different approach to speed up adoption of shorepower, may come through new environmental regulations that can either target local pollutants (such as PM emissions, NOx, or Black Carbon), or through an increase in the fuel price due to a potential tax levy on bunker fuel, or the repercussions of the global sulphur cap on fuel availability. Additional research could consider a more refined economic evaluation of $\mathrm{CI}$ for the stakeholders considering various uncertainties that were not examined in this work. For example the impacts of berth availability during low penetration rates of ships and berths, or the optimal number of how many berths to convert in a given terminal. Interesting research questions in the domain of CI from a Management Science perspective may include the impact of a potential induction of the maritime sector in emissions trading systems (ETS) that the European Commission is contemplating, and the integration of berth scheduling problems in the presence of CI berths. This modelling framework can be used to assess the efficiency of this technology and compare it with other solutions. 


\section{References}

Arduino, G., Murillo, D. C., and Ferrari, C. (2011). Key factors and barriers to the adoption of cold ironing in Europe (No. 1115).

Ataergin, V. S. (2015). Powership's Identity and MARPOL Convention Application. Journal of Shipping and Ocean Engineering, 5, 203-218.

CARB (2017). Shore Power for Ocean-going Vessels. Available at: https://www.arb.ca.gov/ports/shorepower/shorepower.htm (accessed May, 2017)

Corbett, J. J., Winebrake, J. J., Green, E. H., Kasibhatla, P., Eyring, V., \& Lauer, A. (2007). Mortality from ship emissions: a global assessment. Environ. Sci. Technol, 41(24), 8512-8518

Cullinane, K., Tseng, P. H., \& Wilmsmeier, G. (2016). Estimation of container ship emissions at berth in Taiwan. International Journal of Sustainable Transportation, 10(5), 466-474.

Davarzani, H., Fahimnia, B., Bell, M., \& Sarkis, J. (2016). Greening ports and maritime logistics: A review. Transportation Research Part D: Transport and Environment, 48, 473-487.

Deniz, C., \& Durmuşoğlu, Y. (2008). Estimating shipping emissions in the region of the Sea of Marmara, Turkey. Science of the total environment, 390(1), 255-261.

Dragović, B., Tzannatos, E., Tselentis, V., Meštrović, R., \& Škurić, M. (2015). Ship emissions and their externalities in cruise ports. Transportation Research Part D: Transport and Environment.

Environmental Protection Agency - EPA (2017). Summary tables eGrid2014. Available at: https://www.epa.gov/sites/production/files/2017-02/documents/egrid2014_summarytables_v2.pdf (accessed December 2017).

ESPO (2012). Green Guide: towards excellence in ort environmental management and sustainability. Available at: https://www.espo.be/media/espopublications/espo_green\%20guide_october\%202012_final.pdf (accessed January, 2018)

European Commission (2017). EU energy in figures. Statistical Pocketbook. Available at: https://publications.europa.eu (Accessed June 2018)

European Commission (2014). Directive 2014/94/EU on the development of alternative fuels infrastructure. Official Journal of the European Union L307/1

European Commission (2006). Commission Recommendation 2006/339/EC of 8 May 2006 on the promotion of shore-side electricity for use by ships at berth in Community ports. Available at: http://eur-

lex.europa.eu/LexUriServ/LexUriServ.do?uri=OJ:L:2006:125:0038:0042:EN:PDF accessed November 2017.

European Commission. (2005) Directive 2005/33/EC amending Directive 1999/32/EC as regards the sulphur content of marine fuels.

http://www.ops.wpci.nl/_images/_downloads/_original/1264149906_2005eudirectivesulphurcontentofmarinefue $\underline{1 \mathrm{~s} 2005 \text { 33.pdf }}$, accessed August 2017

Fagerholt, K., \& Psaraftis, H. N. (2015). On two speed optimization problems for ships that sail in and out of emission control areas. Transportation Research Part D: Transport and Environment, 39, 56-64.

Fiadomor R. (2009). Assessment of alternative maritime power (cold ironing) and its impact on port management and operations. MSc thesis. World Maritime University. Malmo Sweden.

Golias, M., Boile, M., Theofanis, S., \& Efstathiou, C. (2010). The berth-scheduling problem: Maximizing berth productivity and minimizing fuel consumption and emissions production. Transportation Research Record: Journal of the Transportation Research Board, (2166), 20-27. 
Howey, D. A., Martinez-Botas, R. F., Cussons, B., and Lytton, L. (2011). Comparative measurements of the energy consumption of 51 electric, hybrid and internal combustion engine vehicles. Transportation Research Part D: Transport and Environment, 16(6), 459-464.

\section{IEC/ISO (2012) Cold Ironing—Part 1: High Voltage Shore Connection (HVSC) Systems-General} requirements, IEEE Standard 80005-1

IMO (2018). Shore Power. International Maritime Organization (IMO), London. [Online] Available at: http://glomeep.imo.org/technology/shore-power/ (Accessed July 2018).

IMO (2014). Third IMO GHG Study 2014. International Maritime Organization (IMO), London. [Online] Available at: http://www.iadc.org/wp-content/uploads/2014/02/MEPC-67-6-INF3-2014-Final-Reportcomplete.pdf [accessed April 2017]

IMO (2009). Second IMO GHG Study 2008. International Maritime Organization (IMO), London. [Online] Available at:

http://www.imo.org/en/OurWork/Environment/PollutionPrevention/AirPollution/Documents/SecondIMOGHGS tudy2009.pdf [accessed April 2017]

Innes, A., \& Monios, J. (2018). Identifying the unique challenges of installing cold ironing at small and medium ports-The case of aberdeen. Transportation Research Part D: Transport and Environment, 62, 298-313.

Khersonsky, Y., Islam, M., and Peterson, K. (2007). Challenges of connecting shipboard marine systems to medium voltage shoreside electrical power. Industry Applications, IEEE Transactions on, 43(3), 838-844

Johnson, H., \& Styhre, L. (2015). Increased energy efficiency in short sea shipping through decreased time in port. Transportation Research Part A: Policy and Practice, 71, 167-178.

Lack, D. A., \& Corbett, J. J. (2012). Black carbon from ships: a review of the effects of ship speed, fuel quality and exhaust gas scrubbing. Atmospheric Chemistry and Physics, 12(9), 3985-4000.

Ng, S. K., Loh, C., Lin, C., Booth, V., Chan, J. W., Yip, A. C., ... \& Lau, A. K. (2013). Policy change driven by an AIS-assisted marine emission inventory in Hong Kong and the Pearl River Delta. Atmospheric environment, 76, 102-112.

Paul, D. and Haddadian, V. (2005) Cold ironing - Power System Grounding and Safety Analysis.In Industry Applications Conference, 2005. Fourtieth IAS Annual Meeting. Conference Record of the 2005.Vol. 2, IEEE, pp. $1503-1511$

Prousalidis, J., Antonopoulos, G., Patsios, C., Greig, A., \& Bucknall, R. (2014, September). Green shipping in emission controlled areas: Combining smart grids and cold ironing. In Electrical Machines (ICEM), 2014 International Conference on (pp. 2299-2305). IEEE.

Ricardo-AEA (2014). Update of the Handbook on External Costs of Transport. Report for the European Commission DG MOVE, London.

Saxe, H., and Larsen, T. (2004). Air pollution from ships in three Danish ports. Atmospheric environment, 38(24), 4057-4067.

Sciberras, E. A., Zahawi, B., \& Atkinson, D. J. (2015). Electrical characteristics of cold ironing energy supply for berthed ships. Transportation Research Part D: Transport and Environment, 39, 31-43.

Tichavska, M., \& Tovar, B. (2015). Port-city exhaust emission model: An application to cruise and ferry operations in Las Palmas Port. Transportation Research Part A: Policy and Practice, 78, 347-360.

Tongzon, J., \& Heng, W. (2005). Port privatization, efficiency and competitiveness: Some empirical evidence from container ports (terminals). Transportation Research Part A: Policy and Practice, 39(5), 405-424.

Tseng, P. H., \& Pilcher, N. (2015). A study of the potential of shore power for the port of Kaohsiung, Taiwan: To introduce or not to introduce?. Research in Transportation Business \& Management, 17, 83-91. 
United Nations Conference on Trade and Development - UNCTAD (2016) Review of maritime transport. UNCTAD/RMT/2016, United Nations publication. http://unctad.org/en/PublicationsLibrary/rmt2016_en.pdf, accessed June 2017

Winkel R., Weddige U., Johnsen D., Hoen V. and Papaefthymiou G. (2015). Potential for Shore Side Electricity in Europe - Final Report. Available at: http://www.ecofys.com/files/files/ecofys-2014-potential-for-shore-sideelectricity-in-europe.pdf (accessed April 2015)

Yeo, G. T., Roe, M., \& Dinwoodie, J. (2008). Evaluating the competitiveness of container ports in Korea and China. Transportation Research Part A: Policy and Practice, 42(6), 910-921.

Zis, T., and Psaraftis, H. N. (2018). Operational measures to mitigate and reverse the potential modal shifts due to environmental legislation. Maritime Policy \& Management, 1-16.

Zis, T., and Psaraftis, H. N. (2017). The implications of the new sulphur limits on the European Ro-Ro sector. Transportation Research Part D: Transport and Environment, 52, 185-201.

Zis, T., North, R. J., Angeloudis, P., Ochieng, W. Y., \& Bell, M. G. (2015). Environmental balance of shipping emissions reduction strategies. Transportation Research Record: Journal of the Transportation Research Board, (2479), 25-33.

Zis, T., North, R. J., Angeloudis, P., Ochieng, W. Y., \& Bell, M. G. H. (2014). Evaluation of cold ironing and speed reduction policies to reduce ship emissions near and at ports. Maritime Economics \& Logistics, 16(4), 371398. 